\title{
PERSPEKTIF MUHAMMADIYAH PANCASILA SEBAGAI DARUL AHDI WA SYAHADAH
}

\author{
Yayuk Kusumawati, M. Pd. \\ Institut Agama Islam (IAI) Muhammadiyah Bima \\ Jln. Anggrek No. 16 Ranggo Na'e Kota Bima \\ yayukalkhansa@gmail.com
}

\section{Abstrak}

Muhammadiyah adalah salah satu organisasi terbesar di Indonesia, tentunya dalam perjalanan membangun organisasi tidaklah mudah butuh perjuangan ekstra dalam menghadapi berbagai masalah kehidupan, muhammadiyah lahir pada tanggal 18 November 1912 oleh pendiri KH.Ahmad Dahlan, salah datu pelopor pendidikan pertama di Indonesia yang mendirikan sekolah yang terdapat di Belitung sebelum munculnya Ki Hajar dewantara hal ini adalah sebagai bentuk manifestasi dari gerakan untuk membangun dan menyadarkaan bangsa Indonesia untuk mencerdaskan generasi bangsa dari keterpurukan penjajah, dalam perjalanan membangun organisasi para tokoh tidak bertentangan dengan hadirnya pancasila sebagai ideology bangsa seperti contoh ada tiga tokoh penting Muhammadiyah yaitu Ki Bagus Hadikusumo, Prof. Kahar Mudzakir dan Mr. Kasman Singodimenjo bersama para tokoh lainnya mengambil peran aktif di Badan Persiapan Usaha Kemerdekaan Indonesia (BPUPKI) dan panitia persiapan kemerdekaan Indonesia (PPKI) serta masih baanyak tokoh lainnya, maka jelas bahwa negara pancasila merupakan hasil kesepakatan, kesaksian, dan konsesus bersama (dar al-ahdi) yang dimana muhammadiyah juga terlibat di dalamnya melalui para 
tokohnya sebagai salah saatu perintis kemerdekaan bangsa Indonesia.

\section{Keywords: Muhammadiyah, Pancasila, Darul Ahdi Wa Syahadah.}

\section{Pendahuluan}

Negara Kesatuan Republik Indonesia yang diproklamasikan pada 17 Agustus 1945 merupakan anugerah Allah atas perjuangan seluruh rakyat yang mengandung jiwa, pikiran, dan cita-cita luhur kemerdekaan. Spirit keruhanian yang menjiwai lahirnya Negara Indonesia itu tertuang dalam tiga alinea awal Pembukaan UUD 1945, "Bahwa sesungguhnya kemerdekaan itu ialah hak segala bangsa dan oleh sebab itu, maka penjajahan di atas dunia harus dihapuskan, karena tidak sesuai dengan peri-kemanusiaan dan peri-keadilan. Dan perjuangan pergerakan kemerdekaan Indonesia telah sampailah kepada saat yang berbahagia dengan selamat sentosa menghantarkan rakyat Indonesia ke depan pintu gerbang kemerdekaan Negara Indonesia, yang merdeka, bersatu, berdaulat, adil, dan makmur. Atas berkat rahmat Allah Yang Maha Kuasa dan dengan didorongkan oleh keinginan luhur, supaya berkehidupan kebangsaan yang bebas, maka rakyat Indonesia menyatakan dengan ini kemerdekaannya".

Tujuan didirikannya Negara Republik Indonesia ialah "melindungi segenap bangsa Indonesia dan seluruh tumpah darah Indonesia dan untuk memajukan kesejahteraan umum, mencerdaskan kehidupan bangsa, dan ikut melaksanakan ketertiban dunia yang berdasarkan kemerdekaan, perdamaian abadi dan keadilan sosial." Konstitusi dasar yang menjadi landasan bernegara itu dirumuskan dalam "suatu UndangUndang Dasar Negara Indonesia, yang terbentuk dalam suatu susunan Negara Republik Indonesia yang berkedaulatan rakyat 
dengan berdasarkan kepada Ketuhanan Yang Maha Esa, Kemanusiaan Yang Adil dan Beradab, Persatuan Indonesia, Kerakyatan yang dipimpin oleh hikmat kebijaksanaan dalam Permusyawaratan/Perwakilan, serta dengan mewujudkan suatu Keadilan sosial bagi seluruh rakyat Indonesia.". Adapun dasar dan ideologi negara yang fundamental ialah Pancasila yang disebut oleh Soekarno dalam Pidato 1 Juni 1945 sebagai Philosofische Grondslag yaitu "fundamen, filsafat, pikiran yang sedalam-dalamnya, jiwa, hasrat yang sedalam dalamnya untuk di atasnya didirikan gedung Indonesia Merdeka yang kekal dan abadi.".

Diktum-diktum mendasar dalam Pembukaan UUD 1945 itu sungguh penting dan mendasar karena mengandung jiwa, filosofi, pemikiran, dan cita-cita bernegara untuk dihayati dan diwujudkan dalam kehidupan kebangsaan oleh seluruh warga dan sebagai Negara Pancasila yang relijius dan bukan suatu negara sekuler yang memisahkan atau menjauhkan nilai-nilai ketuhanan dan keagamaan dari denyut nadi kehidupan kebangsaan dan kenegaraan. Kelahiran dan kehadiran Negara Indonesia yang berjiwa Ketuhanan dan Keagamaan itu memiliki matarantai sejarah yang panjang khususnya dengan keberadaan umat Islam dan kerajaankerajaan Islam di masa lampau.

Di negeri kepulauan ini telah lahir kerajaan-kerajaan besar yang tersebar di seluruh penjuru Nusantara seperti Tarumanegara, Kutai, Sriwijaya, Kediri, Singosari, Majapahit, Samudra Pasai, Aceh Darussalam, Siak, Demak, Pajang, Mataram, Banten, Cirebon, Pajajaran, Ternate, Tidore, Gowa, Buton, Bone, Sumbawa, Bima, Pagaruyung, Banjar, Karangasem, Madura, Larantuka, Papua, dan kerajaan-kerajaan lainnya sebagai tonggak sejarah bangsa. Dalam perjalanan sejarah itu peranan umat Islam dan kerajaan-kerajaan Islam sangatlah penting dan strategis dalam perjuangan kemerdekaan dan pembentukan Indonesia sebagai negara-bangsa. Peranan umat Islam yang bersejarah itu 
menemukan bentuknya yang moderen dan dan terorganisir pada awal abad ke 20 yang ditandai oleh lahirnya gerakan kebangkitan nasional dari organisasi-organisasi Islam seperti Jami'atul Khair (1905),Sarikat Dagang Islam (1905), Sarekat Islam (1911), Muhammadiyah (1912), Al-Irsyad (1914), Persatuan Islam (1923), Nahdlatul Ulama (1926), dan lain-lain. Kongres Wanita pertama tahun 1928, di mana 'Aisyiyah sebagai organisasi perempuan Muhammadiyah menjadi salah satu pemrakarsa dan penyelenggara, merupakan tonggak kebangkitan perempuan Indonesia dan menjadi bagian integral dari pergerakan nasional ${ }^{1}$.

Arus pergerakan nasional dari umat Islam tersebut bersatu dengan komponen kebangkitan nasional lainnya menjadi sumber kekuatan dan modal perjuangan bangsa yang melahirkan kemerdekaan Indonesia yang diproklamasikan pada tanggal 17 Agustus 1945. Setelah merdeka, Indonesia mengalami dinamika kehidupan yang kompleks sebagaimana tercermin dalam beberapa periode penyelenggara negara dengan penuh makna dan kesungguhan. Di dalamnya terkandung suasana kebatinan dan spiritualitas yang didasari jiwa keagamaan dari para pendiri bangsa yang mengakui bahwa kemerdekaan dan berdirinya Negara Indonesia itu selain atas dorongan keinginan luhur dari seluruh rakyat, pada saat yang sama merupakan berkat rahmat Allah Yang Maha Kuasa. Jika dirujuk pada Sila Pertama Pancasila, yaitu "Ketuhanan Yang Maha Esa", maka negara Indonesia itu tidak dapat dipisahkan dari jiwa, pikiran, pemerintahan di era Revolusi (1945-1949), Demokrasi Parlementer (1950-1959), Orde Lama (1959-1966), Orde Baru (1966-1998), dan Reformasi sejak tahun $1998^{2}$.

${ }^{1}$ Muh. Tahir Azhary, 2005. Negara Hukum ; Suatu studi tentang prinsipprinsipnya dilihat dari segi hukum Islam, Implementasinya pada periode Negara Madinah dan masa kini, Jakarta : Kencana.hlm 54

${ }^{2}$ Ibid. hlm 60 
Dalam perjalanan Indonesia pasca kemerdekaan itu umat Islam melalui organisasi-organisasi Islam dan peran para tokohnya maupun melalui gerakan massa umat mengambil peranan yang signifikan. Dalam perjalanan bangsa yang sarat dinamika itu selain muncul berbagai krisis dan permasalahan, di samping pada saat yang sama terdapat kemajuan-kemajuan yang cukup berarti sebagai hasil dari pembangunan nasional yang dilakukan pada setiap periode dan menjadi tonggak bagi perkembangan Indonesia ke depan. Namun diakui bahwa pasca kemerdekaan itu Indonesia banyak menghadapi permasalahan dan tantangan yang berat dan kompleks. Kehidupan bangsa dan negara Indonesia setelah puluhan tahun merdeka sampai saat ini masih ditandai kejumudan (stagnasi), dan peluruhan (distorsi), dan penyimpangan (deviasi) dalam berbagai bidang kehidupan kebangsaan ditimbang dari jiwa, pemikiran, dan cita-cita nasional yang diletakkan oleh para pendiri bangsa sebagaimana termaktub dalam Pembukaan Undang-Undang Dasar (UUD) 1945.

Meskipun terdapat banyak kemajuan, seperti dalam kehidupan demokrasi dan hak asasi manusia, tingkat pertumbuhan ekonomi, dan suasana kemajemukan bangsa yang terpelihara dengan baik, tak dapat dipungkiri masih banyak persoalan rumit dan mendesak yang harus segera diselesaikan. Di antara masalah yang cukup serius adalah korupsi yang masif, penegakan hukum yang lemah, kesenjangan sosial yang melebar, sumberdaya alam yang dieksploitasi dan dikuasai pihak asing, dan hal-hal lain yang berdampak luas pada kehidupan kebangsaan yang jauh dari citacita nasional. Kehidupan kebangsaan masih diwarnai oleh krisis moral dan etika, disertai berbagai paradoks dan pengingkaran atas nilai-nilai keutamaan yang selama ini diakui sebagai nilai-nilai luhur budaya bangsa. Kenyataan ini ditunjukkan oleh perilaku elite dan warga masyarakat yang korup, konsumtif, hedonis, materialistik, suka 
menerabas, dan beragam tindakan menyimpang lainnya. Sementara nilai-nilai Ketuhanan dan Keagamaan yang bebasis Tauhid. Spirit ruhaniah itu makin menguat manakala dikaitkan dengan pasal 29 UUD 1945 yang mengakui keberadaan dan kemerdekaan umat beragama untuk menjalankan keyakinan dan kepercayaan agamanya.

Situasi demikian jelas bertentangan dengan makna dan cita-cita kemerdekaan. Karenanya Muhammadiyah memandang penting langkah rekonstruksi kehidupan kebangsaan yang bermakna dalam seluruh aspek kehidupan khususnya politik, ekonomi, dan budaya menuju Indonesia Berkemajuan. Indonesia Berkemajuan merupakan kondisi bangsa dan negara yang maju, adil, makmur, bemartabat, dan berdaulat dengan menjunjung tinggi nilai-nilai dasar yang terkandung dalam lima sila Pancasila dan cita-cita kemerdekaan yang diletakkan fondasinya oleh para pendiri bangsa tahun 1945. Bangsa Indonesia sesungguhnya memiliki nilai-nilai keutamaan yang mengkristal menjadi modal sosial dan budaya penting untuk maju menjadi unggul dan berperadaban tinggi. Di antara nilai-nilai itu adalah daya juang, tahan menderita, mengutamakan harmoni, dan gotong royong.

Nilai-nilai keutamaan tersebut masih relevan, namun memerlukan penyesuaian dan pengembangan sejalan dengan dinamika dan tantangan zaman. Tantangan globalisasi yang meniscayakan orientasi kepada kualitas, persaingan dan daya saing menuntut bangsa Indonesia memiliki karakter yang bersifat kompetitif, dinamis, berkemajuan, dan berkeunggulan disertai ketangguhan dalam menunjukkan jatidiri bangsa. Dalam lintasan perjuangan kemerdekaan dan lahirnya Negara Kesatuan Republik Indonesia (NKRI) itu sesungguhnya terkandung jiwa, pikiran, dan cita-cita yang fundamental untuk diwujudkan dalam kehidupan kebangsaan menuju kehidupan kebangsaan yang berkemajuan. Seluruh komponen nasional dan generasi penerus bangsa, termasuk umat Islam sebagai kekuatan mayoritas, wajib 
memahami keberadaan Negara Indonesia yang didirikan dengan penuh perjuangam berat itu untuk dibangun menjadi Negarabangsa yang berkemajuan sesuai dengan tuntutan zaman.

Bagi mereka yang menduduki jabatan-jabatan publik berkewajiban menjalankan fungsi utama pemerintahan sesuai dengan jiwa, falsafah, pemikiran, dan cita-cita nasional sebagaimana dileletakkan fondasinya oleh para pendiri bangsa. Pengingkaran terhadap nilai-nilai luhur kebangsaan itu merupakan bentuk penyelewengan dan penghianatan atas idealisme kemerdekaan. Sebaliknya setiap usaha untuk mewujudkan nilai dan cita-cita nasional itu merupakan bukti kesungguhan untuk membawa Indonesia sebagai bangsa dan negara yang maju, adil, makmur, bermartabat, dan berdaulat di tengah dinamika perkembangan zaman. Segenap kekuatan nasional-harus memiliki tekad yang kuat dan bersatu untuk menjadikan Indonesia sebagai Negara Pancasila yang berdiri tegak di atas jiwa, pikiran, dan cita-cita nasional 1945 yang penting dan luhur itu.

\section{Pengertian Pancasila dan Darul Ahdi Wa Syahadah}

Secara Etimologi kata "Pancasila" berasal dari bahasa Sansekerta dari India (bahasa kasta Brahmana) yaitu panca yang berarti "lima" dan silayang berarti "dasar". Jadi secara harfiah, "Pancasila" dapat diartikan sebagai "lima dasar"3. Pengertian Pancasila ialah sebagai dasar negara seperti dimaksud dalam bunyi Pembukaan UUD 1945 Alinea IV(4) yang secara jelas menyatakan, ialah kurang lebih sebagai berikut

"Kemudian dari pada itu untuk dapat membentuk suatu pemerintahan negara Indonesia yang melindungi segenap bangsa Indonesia serta seluruh tumpah darah Indonesia dan untuk memajukan kesejahteraan umum, mencerdaskan kehidupan bangsa, serta ikut dalam melaksanakan ketertiban dunia yang berdasarkan kemerdekaan,

${ }^{3}$ Kaelan,2014. Pendidikan Pancasila.Yogyakarta : PT Paradigma. Hal. 12

Sangaji Jurnal Pemikiran Syariah dan Hukum 
perdamaian abadi serta keadilan sosial maka disusunlah kemerdekaan kebangsaan Indonesia itu dalam suatu Undang-Undang suatu Dasar Negara Indonesia yang berbentuk dalam suatu susunan negara Republik Indonesia yang berkedaulatan rakyat dengan berdasarkan kepada Ketuhanan Yang Maha Esa, Kemanusiaan yang adil serta beradab, Persatuan Indonesia, serta Kerakyatan yang dipimpin oleh hikmat kebijaksanaan dalam permusyawaratan perwakilan, serta untukmewujudkan suatu Keadilan sosial bagi seluruh rakyat Indonesia."

Darul ahdi artinya negara tempat kita melakukan konsensus nasional. Negara kita berdiri karena seluruh kemajemukan bangsa, golongan, daerah, kekuatan politik, sepakat untuk mendirikan Indonesia ${ }^{4}$.

\section{Konsep Negara Pancasila}

Indonesia adalah negara hukum sebagaimana tercantum dalam Pasal 1 Angka 3 Undang-Undang Dasar 1945 yang menyatakan secara tegas bahwa Negara Republik Indonesia adalah negara hukum, dengan demikian dalam praktik kehidupan bermasyarakat, berbangsa dan bernegara harus memenuhi dan mewujudkan persyaratan dan prinsip-prinsip yang terdapat dalam negara hukum. Dengan dirumuskannya pola Indonesia adalah negara yang berdasarkan hukum di dalam UUD 1945, maka semua adalah pelaku, pendukung dan pelaksana sebagaimana telah digariskan bahwa para penyelenggara negara (policy executers) dan para pemimpin pemerintahan (policy makers) wajib memiliki semangat yang baik yaitu sesuai dengan jiwa Pancasila dan Undang-Undang Dasar $1945^{5}$.

${ }^{4}$ haedar nastir, 2014. negara pencasila sebagai darul ahdi wa syahadah, pernyataan PP Muhammadiyah

${ }^{5}$ Padmo Wahjono, Indonesia Negara Berdasarkan Atas Hukum, Jakarta : Ghalia Indonesia, 1986, Hlm 21. 
Dasar mengenai konsep negara hukum Indonesia tidak dapat dipisahkan dari keberadaan Pancasila sebagai dasar negara dan sumber dari segala sumber hukum dan jiwa bangsa (volksgeist) Indonesia, dengan kata lain bahwa Pancasila menjiwai seluruh kehidupan negara hukum Indonesia. Konsep negara hukum Pancasila merupakan konsep negara hukum yang dikembangkan dan diterapkan di Indonesia yang didasarkan pada sistem hukum Pancasila. Konsep negara hukum Pancasila memiliki ciri khas yang terdapat pada falsafah bangsa dan negara Indonesia yakni Pancasila ${ }^{6}$.

Konsep negara hukum Pancasila yang dianut dan diterapkan di Indonesia tidaklah murni mengadopsi konsep negara hukum rechttstaat di negara-negara yang menganut sistem hukum civil law, maupun konsep rule of law di negara-negara yang menganut sistem hukum common law, melainkan menganut dan menerapkan konsep negara hukum yang disesuaikan dengan kondisi dan jiwa bangsa Indonesia yakni konsep negara hukum Pancasila yang secara historis lahir bukan karena perlawanan terhadap absolutisme yang dilakukan oleh penguasa atau raja sebagaimana latar belakang munculnya pemikiran rechttstaat dan rule of law, melainkan lahir karena adanya keinginan bangsa Indonesia untuk terbebas dari belenggu imperialisme dan kolonialisme yang dilakukan oleh penjajahan Belanda ${ }^{7}$.

Konsep negara hukum Pancasila lahir karena adanya dorongan dari seluruh elemen bangsa Indonesia untuk memerdekakan diri dari penjajahan kolonialisme. Keinginan untuk merdeka sebagaimana tercantum dalam pembukaan UUD 1945 alinea II yang menyatakan bahwa ${ }^{8}:$ “...dan perjuangan

6 Yopi Gunawan dan Kristian, Perkembangan Konsep Negara Hukum \& Negara Hukum Pancasila, Bandung : Refika Aditama, 2015, Hlm 92

7 ibid hal 86

8 Teguh Presetyo dan Arie Purnomosidi, Membangun Hukum Berdasarkan Pancasila, Bandung : Nusa Media, 2014, Hlm 38-39.

Sangaji Jurnal Pemikiran Syariah dan Hukum 
kemerdekaan Indonesia telah sampailah kepada saat yang berbahagia dengan selamat sentausa mengantarkan rakyat Indonesia ke depan pintu gerbang kemerdekaan Indonesia, yang merdeka, bersatu, adil dan makmur".

Konsep negara hukum Pancasila yaitu konsep negara hukum di mana satu pihak harus memenuhi kriteria dari konsep negara hukum pada umumnya yaitu ditopang tiga pilar pengakuan dan perlindungan hak asasi manusia, peradilan yang bebas dan tidak memihak, dan asas legalitas dalam arti formal maupun material, dan di lain pihak, diwarnai oleh aspirasiaspirasi keindonesiaan yaitu lima nilai fundamental dari Pancasila yang dirumuskan secara materil didasarkan pada cara pandang (paradigma) bangsa Indonesia dalam bernegara yang bersifat integralistik khas Indonesia, dan secara formal yuridis dengan memperhatikan ketentuan dalam UUD 1945 dengan membandingkan dengan konsep negara hukum liberal yaitu rechttstaat dan rule of law . $^{9}$

Padmo Wahjono mengemukakan pemikirannya tentang negara hukum Indonesia berkaitan dengan pengaruh konsep rechtsstaat sebagaimana yang tercantum dalam penjelasan UUD 1945, sebagai berikut ${ }^{10}$ : Indonesia adalah negara yang berdasarkan atas hukum, dengan rumusan rechtsstaat diantara kurang dengan anggapan bahwa pola yang diambil tidak menyimpang dari pengertian negara hukum pada umumnya (genusbegrip), disesuaikan dengan keadaan di Indonesia, digunakan dengan ukuran pandangan hidup maupun pandangan bernegara kita. Hlm 86-88.

9 A. Mukthie Fadjar, Tipe Negara Hukum, Malang : Bayu Media, 2005,

10 Marwan Efendy, Teori Hukum Dari Perspektif Kebijakan, Perbandingan, dan Harmonisasi Hukum Pidana, Jakarta : Referensi, 2014, Hlm 55. 
Berkaitan dengan negara hukum di Indonesia, Muhammad Yamin mengemukakan pemikirannya sebagai berikut ${ }^{11}$ :

"Kekuasaan yang dilakukan oleh pemerintah Republik Indonesia itu hanya berdasarkan dan berasal dari undangundang dan sekali-kali tidak berdasarkan kekuasaan senjata, kekuasaan sewenang-wenang atau kepercayaan, bahwa kekuatan badanlah yang boleh memutuskan segala pertikaian dalam negara. Republik Indonesia ialah negara hukum (rechtsstaat / goverment under of law) tempat keadilan yang tertulis berlaku; bukanlah negara polisi atau negara militer, bukanlah pula negara kekuasaan (machtsstaat). Republik Indonesia ialah negara yang melaksanakan keadilan yang tertuliskan dalam undang-undang. Warga negara diperintah dan diperlakukan oleh undang-undang keadilan yang dibuat oleh rakyat sendiri".

Oemar Senoadji mengemukakan bahwa negara hukum Pancasila mempunyai ciri-ciri khas Indonesia dengan menggunakan Pancasila sebagai dasar pokok dan sumber hukum. Ciri pokok dalam negara hukum Pancasila adalah adanya jaminan terhadap freedom of religion atau kebebasan beragama yang mempunyai konotasi positif bahwa tiada tempat bagi atheisme atau propaganda anti agama. Ciri berikutnya adalah tiada pemisahan yang rigid dan mutlak antara negara dan agama yang berada dalam hubungan yang harmonis, berbeda dengan negara sekuler seperti Amerika Serikat yang menganut doktrin pemisahan agama dan negara ${ }^{12}$.

11 Teguh Presetyo dan Arie Purnomosidi, Op cit, Hlm 40-41

12 Muh. Tahir Azhary, Negara Hukum ; Suatu studi tentang prinsipprinsipnya dilihat dari segi hukum Islam, Implementasinya pada periode Negara Madinah dan masa kini, Jakarta : Kencana, 2005, Hlm 93-94.

Sangaji Jurnal Pemikiran Syariah dan Hukum 
Konsep negara hukum yang berkembang Indonesia mempunyai ciri-ciri ${ }^{13}$ :

1. Pengakuan dan perlindungan terhadap hak asasi manusia;

2. Pancasila menjiwai setiap peraturan hukum dan pelaksanaannya;

3. Asas kekeluargaan merupakan titik tolak negara hukum Indonesia;

4. Peradilan yang bebas dan tidak dipengaruhi kekuatan manapun;

5. Partisipasi warga secara luas.

Negara hukum Pancasila adalah suatu negara hukum yang bercirikan atau berlandaskan pada nilai-nilai serta berlandaskan pada identitas dan karakteristik yang terdapat pada Pancasila. Nilai-nilai yang menjadi landasan bagi negara hukum pancasila yaitu Ketuhanan yang maha Esa, kemanusian yang adil dan beradab, persatuan Indonesia, kerakyatan yang dipimpin oleh hikmat kebijaksanaan dalam permusyawaratan perwakilan, keadilan sosial bagi seluruh rakyat Indonesia. Karakteristik Negara Hukum Pancasila yaitu ketuhanan, kekeluargaan, gotong royong dan kerukunan ${ }^{14}$.

Menurut Soepomo bahwa makna asas kekeluargaan yang terkandung dalam negara hukum Pancasila berarti bahwa ${ }^{15}$ :

1. Sistem yang terkandung dalam UUD adalah sistem kekeluargaan. Dengan demikian negara hukum Pancasila harus dilandasi dan berpedoman kepada aliran pikiran kekeluargaan tersebut.

2. Berdasarkan asas kekeluargaan itu, aliran yang diterima adalah pengertian negara persatuan. Dalam negara persatuan

13 Bahder Johan Nasution, Negara Hukum Dan Hak Asasi Manusia, Bandung : Mandar Maju, 2012, Hlm 80.

14 Teguh Presetyo dan Arie Purnomosidi, Op cit, Hlm 48.

${ }^{15}$ Ibid, 2014, Hlm 54 
tersebut dikehendaki adanya perlindungan yang meliputi segenap bangsa dan rakyat Indonesia. Negara hukum Pancasila merupakan negara keluarga bangsa Indonesia yang mengatasi segala golongan, mengatasi segala paham golongan, mengatasi segala paham perseorangan.

3. Berdasarkan asas kekeluargaan tersebut, maka negara hukum Pancasila menganut paham kedaulatan rakyat yang berdasarkan kepada kerakyatan dan permusyawaratan perwakilan yang diwujudkan dalam suatu lembaga yang bernama Majelis Permusyawaratan Rakyat dan Dewan Perwakilan Rakyat.

4. Berdasarkan pada asas kekeluargaan tersebut, maka negara hukum Pancasila berdasarkan kepada ketuhanan yang maha esa menurut dasar kemanusiaan yang adil dan beradab.

Soediman Kartohadiprodjo mengemukakan pemikirannya dalam Simposium Indonesia Negara Hukum, bahwa negara hukum Pancasila bercirikan unsur-unsur yaitu ${ }^{16}$ :

a. Jiwa kekeluargaan;

b. Musyawarah mufakat berlandaskan hukum adat;

c. Melindungi rakyat dari tindakan pemerintah yang sewenangwenang;

d. Mengutamakan tugas dan tanggungjawab bagi lembagalembaga negara dan bukan mengutamakan kekuasaan.

Padmo Wahjono menjelaskan bahwa konsep negara hukum Pancasila mengadung lima unsur yaitu ${ }^{17}$ :

1. Pancasila merupakan sumber dari segala sumber hukum, yang berarti kita menghendaki satu sistem hukum nasional

16 Dewa Gede Atmadja, et all, Teori Konstitusi \& Negara Hukum, Malang : Setara Press, 2015., Hlm 156.

17 ibid 167

Sangaji Jurnal Pemikiran Syariah dan Hukum 
yang dibagun atas dasar wawasan kebangsaan, wawasan nusantara dan wawasan bhineka tungal ika.

2. Majelis Permusyawaratan Rakyat berwenang mengubah, menetapkan Undang-Undang Dasar yang melandasi segala peraturan perundang-undangan yang dibentuk oleh Dewan Perwakilan Rakyat bersama-sama dengan Presiden.

3. Pemerintahan berdasarkan sistem konstitusi, yaitu suatu sistem tertentu yang pasti dan yang jelas di mana hukum yang hendak ditegakan oleh negara dan yang membatasi kekuasaan penguasa atau pemerintah agar pelaksanaannya teratur dan tidak simpang siur harus merupakan satu tertib dan satu kesatuan tujuan.

4. Semua warga negara bersamaan kedudukannya dalam hukum dan pemerintahan dan wajib menjunjung hukum dan pemerintahan itu dengan tiada kecualinya.

5. Kekuasaan kehakiman adalah kekuasaan yang merdeka, artinya terlepas dari pengaruh kekuasaan pemerintah.

Pandangan Muhammadiyah terhadap negara pancasila sebagai darul ahdi wa syahadah

Pandangan Muhammadiyah mulai dari PP Muhammadiyah sampai pada struktur kebawahnya menyepakati bahwa organisasi Muhammadiyah tidak bertentangan dengan ideologi di negara Indonesia yaitu ideologi pancasila. Negara pancasila merupakan hasil consensus (kesepakatan) nasional dan tempat pembuktian atau kesaksian untuk menjadi negeri yang aman dan damai menuju kehidupan yang maju, adil, makmur, bermartabat, dan berdaulat dalam naungan ridha Allah SWT. Hasil kesepakatan atau consensus itulah yang diistilahkan dengan Darul 'Ahdi, Negara Kesepakatan Nasional. Sedangkan Negara Kesaksian diistilahkan dengan Darusy Syahadah. Sehingga Indonesia sebagai Negara Pancasila, dimaknai oleh 
Muhammadiyah sebagai Negara hasil kesepakatan nasional dan Negara kesaksian, Darul 'Ahdi Wa Syahadah' ${ }^{18}$.

Pandangan kebangsaan Muhammadiyah ini sejalan dengan cita-cita Islam tentang Negara idaman yaitu, Baldatun Thayibatun Wa Rabbun Ghafur, yaitu negeri yang baik dan berada dalam ampunan Allah SWT. Negara ideal itu diberkahi karena penduduknya memiliki sifat-sifat ${ }^{19}$ :

\section{Beriman dan bertaqwa}

"Jikalau Sekiranya penduduk negeri-negeri beriman dan bertakwa, pastilah Kami akan melimpahkan kepada mereka berkah dari langit dan bumi, tetapi mereka mendustakan (ayat-ayat Kami) itu, Maka Kami siksa mereka disebabkan perbuatannya." (QS. Al A'raf : 96)

\section{Beribadah dan memakmurkannya}

"dan aku tidak menciptakan jin dan manusia melainkan supaya mereka mengabdi kepada-Ku." (QS. Adz Dzariyat : 56) "dan kepada Tsamud (kami utus) saudara mereka shaleh. Shaleh berkata: "Hai kaumku, sembahlah Allah, sekali-kali tidak ada bagimu Tuhan selain Dia. Dia telah menciptakan kamu dari bumi (tanah) dan menjadikan kamu pemakmurnya ${ }^{20}$, karena itu mohonlah ampunanNya, kemudian bertobatlah kepada-Nya, Sesungguhnya Tuhanku Amat dekat (rahmat-Nya) lagi memperkenankan (doa hamba-Nya)." (QS. Hud : 61)

3. Menjalankan fungsi kekhalifahan dan tidak membuat kerusakan di dalamnya

"dan bila dikatakan kepada mereka:"Janganlah kamu membuat kerusakan di muka bumi21". mereka menjawab: "Sesungguhnya

18 Kumparan.com hasil muktamar ke 47 tahun 2015 dimakassar

19 alqur'an terjemahan Indonesia

20 al-qur'an terjemahan Indonesia, maksudnya: manusia dijadikan penghuni dunia untuk menguasai dan memakmurkan dunia.

21 al-qur'an terjemahan Indonesia,maksudnya: Kerusakan yang mereka perbuat di muka bumi bukan berarti kerusakan benda, melainkan menghasut orang-orang kafir untuk memusuhi dan menentang orang-orang Islam.

Sangaji Jurnal Pemikiran Syariah dan Hukum 
Kami orang-orang yang Mengadakan perbaikan." (QS. Al Baqarah :11 ) "ingatlah ketika Tuhanmu berfirman kepada Para Malaikat: "Sesungguhnya aku hendak menjadikan seorang khalifah di muka bumi." mereka berkata: "Mengapa Engkau hendak menjadikan (khalifah) di bumi itu orang yang akan membuat kerusakan padanya dan menumpahkan darah, Padahal Kami Senantiasa bertasbih dengan memuji Engkau dan mensucikan Engkau?" Tuhan berfirman: "Sesungguhnya aku mengetahui apa yang tidak kamu ketahui." (Al Baqarah : 30)

4. Memiliki relasi hubungan dengan Allah yang harmonis, juga terhadap sesama manusia

"mereka diliputi kehinaan di mana saja mereka berada, kecuali jika mereka berpegang kepada tali (agama) Allah dan tali (perjanjian) dengan manusia ${ }^{22}$, dan mereka kembali mendapat kemurkaan dari Allah dan mereka diliputi kerendahan. yang demikian itu ${ }^{23}$ karena mereka kafir kepada ayat-ayat Allah dan membunuh Para Nabi tanpa alasan yang benar. yang demikian itu ${ }^{24}$ disebabkan mereka durhaka dan melampaui batas." (QS. Ali Imran : 112)

5. Mengembangkan pergaulan global yang setara dan berdasar taqwa

"Hai manusia, Sesungguhnya Kami menciptakan kamu dari seorang laki-laki dan seorang perempuan dan menjadikan kamu berbangsabangsa dan bersuku-suku supaya kamu saling kenal-mengenal. Sesungguhnya orang yang paling mulia diantara kamu disisi Allah ialah orang yang paling taqwa diantara kamu. Sesungguhnya Allah Maha mengetahui lagi Maha Mengenal." (QS. Al Hujuurat : 13)

22 al-qur'an dan terejemahan Indonesia maksudnya: perlindungan yang ditetapkan Allah dalam Al Quran dan perlindungan yang diberikan oleh pemerintah Islam atas mereka.

${ }^{23}$ Yakni: ditimpa kehinaan, kerendahan, dan kemurkaan dari Allah.

24 Yakni: kekafiran dan pembunuhan atas Para nabi-nabi. 


\section{Kesimpulan}

Muhammadiyah menetapkan Negara pancasila sebagai darul ahdi wa syahadah. Muhammadiyah berpendapat bahwa NKRI berdasarkan pancasila adalah bentuk Negara yang ideal dan karenanya harus dipertahankan, muhammadiyah sebagai bagian tak terpisahkan dari masyarakat dan bangsa Indonesia berusaha mewujudkan Indonesia yang berkemajuan sebagai amanat pembukaan UUD 1945.demi keutuhan dan masa depan indoenesia semua pihak hendaknya berpikir dan bertindak dalam jiwa dan koridor persatuan Indonesia dengan menjauhi pertentangan tentang sejarah kelahiran dan perkemabngan rumusan pancasila. Tugas sejarah bangsa Indonesia adalah bagaimana menjaga dan melaksanakan pancasila secara sungguhsungguh dalam semua aspek kehidupan berbangsa dan bernegara, semua pihak hendaknya belajar dari sejarah bahwa berbagai usaha mengubah rumusan dasar Negara pancasila dan pembukaan undang-undang dasar 1945 menimbulkan kekacauan politik yang merusak persatuan bangsa dan Negara Indonesia.

Sangaji Jurnal Pemikiran Syariah dan Hukum 


\section{Daftar Pustaka}

A. Mukthie Fadjar, 2005.Tipe Negara Hukum, Malang : Bayu Media.

Bahder Johan Nasution, 2012. Negara Hukum Dan Hak Asasi Manusia, Bandung : Mandar Maju,

I Dewa Gede Atmadja, 2015. et all, Teori Konstitusi \& Negara Hukum, Malang : Setara Press,

Kaelan,2014. Pendidikan Pancasila.Yogyakarta : PT Paradigma.

Http:// Kumparan.com/ Hasil muktamar muhammadiyah di Makassar

Marwan Efendy, 2014. Teori Hukum Dari Perspektif Kebijakan, Perbandingan, dan Harmonisasi Hukum Pidana, Jakarta : Referensi,

Mahmud Yunus.2006. Kamus Lengkap Arab-Indonesia, Jakarta:PT rineka cipta

Muh. Tahir Azhary, 2005. Negara Hukum ; Suatu studi tentang prinsip-prinsipnya dilihat dari segi hukum Islam, Implementasinya pada periode Negara Madinah dan masa kini, Jakarta : Kencana.

Padmo Wahjono, 1986. .Indonesia Negara Berdasarkan Atas Hukum, Jakarta : Ghalia Indonesia.

Teguh Presetyo dan Arie Purnomosidi, 2014.Membangun Hukum Berdasarkan Pancasila, Bandung : Nusa Media.

Yopi Gunawan dan Kristian, 2015.Perkembangan Konsep Negara Hukum \& Negara Hukum Pancasila, Bandung : Refika Aditama 